\title{
ANALISIS PENYEBAB KECACATAN PRODUK SEPATU TERREX AX2 GORETEX DENGAN MENGGUNAKAN METODE FAULT TREE ANALYSIS (FTA) DAN FAILURE MODE AND EFFECT ANALYSIS (FMEA) DI PT.PANARUB INDUSTRI
}

\author{
${ }^{1} \cdot$ Joko Supono, ${ }^{2}$ Lestari \\ ${ }^{1 .}$ Staff Pengajar Program Studi Teknik Industri, Fakultas Teknik \\ Universitas Muhammadiyah Tangerang \\ Jl. Perintis Kemerdekaan I/33, Cikokol, Kota Tangerang \\ Email : joko.supono@yahoo.com
}

\begin{abstract}
A b s trak
Produk cacat merupakan barang atau jasa yang dibuat dalam proses produksi namun memiliki kekurangan yang menyebabkan nilai atau mutunya kurang baik atau kurang sempurna. PT. Panarub Industry adalah salah satu perusahaan yang bergerak di bidang manufaktur, khususnya sepatu Adidas. Plant 5 cell 1 adalah plant yang memproduksi sepatu jenis outdoor, salah satunya yaitu sepatu model Terrex AX2 Goretex yang mempunyai tingkat kegagalan produk sebesar 13,65\% pada proses produksi dan ini melebihi dari toleransi kegagalan yang ditetapkan perusahaan sebesar 3\%, sehingga perlu dilakukan perbaikan untuk mengurangi jumlah kecacatan produk pada tiap proses produksi. Metodologi penelitian yang dilakukan untuk pemecahan masalah yaitu dengan Fault Tree Analysis (FTA) untuk mengidentifikasi penyebab kecacatan produk berdasarkan proses produksi saat ini, tahapan selanjutnya dengan menggunakan Failure Mode and Effect Analysis (FMEA) untuk mengidentifikasi potensi failure mode, potensi efek kegagalan, penyebab kegagalan, mode-mode deteksi, dan menentukan rating terhadap severity, occurance, dan detection pada risk priority number pada proses produksi. Berdasarkan hasil dari penilaian pada RPN, didapatkan proses sewing dengan skor 576, dan assembling 512 dengan skor 512 mendapatkan nilai RPN tertinggi dan mempunyai tingkat kecacatan mayor. Usulan perbaikan untuk Cacat sewing dengan melakukan pengawasan, training, dan pengecekan mesin secara berkala, penggunaan jarum sesuai standar. Cacat assembling dengan pemeriksaan, pengawasan, penggantian peralatan, dan pengecekan mesin secara berkala. Dengan menerapkan usulan tersebut diharapkan dapat menurunkan tingkat kecacatan produk.
\end{abstract}

Kata Kunci : Produk Cacat, sepatu Terrex AX2 Goretex, Fault Tree Analysis, Failure Mode and Effect Analysis, Risk Priority Number.

\section{PENDAHULUAN}

Produk cacat merupakan barang atau jasa yang di buat dalam proses produksi namun memiliki kekurangan yang menyebabkan nilai atau mutunya kurang baik atau kurang sempurna. Menurut Kholmi dan Yuningsih (2009) produk cacat adalah barang yang di hasilkan tidak dapat memenuhi standar yang telah di tetapkan tetapi masih bisa di perbaiki.

PT. Panarub Industry adalah salah satu perusahaan yang bergerak di bidang manufaktur, merupakan perusahaan yang memproduksi sepatu. Perusahan ini masih mempunyai permasalahan pada banyak jenis dan jumlah produk cacat yang di sebabkan oleh berbagai macam faktor yang menyebabkan penurunan kualitas yang berakibat pada menurunya keuntungan yang di dapatkan perusahaan. 


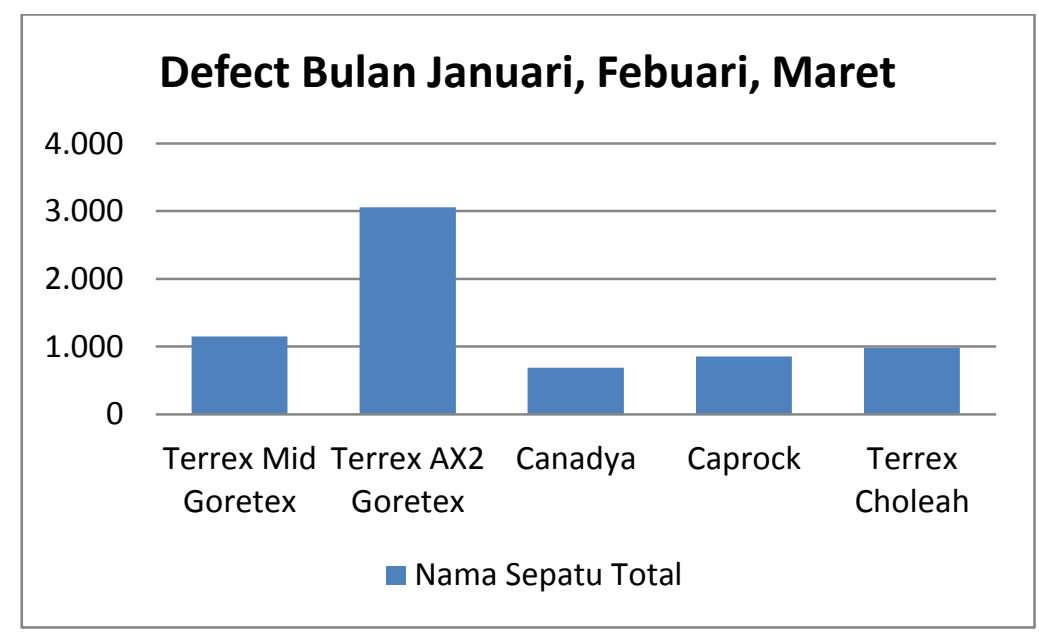

Gambar 1 Diagram Defect Bulan Januari, Febuari, Maret

Berdasarkan digram diatas defect terbanyak diantara kelima model sepatu jenis outdoor pada bulan Januari, Febuari, dan Maret yaitu Terrex AX2 Goretex dengan jumlah defect sebesar 3.058 pasang sepatu atau dengan rate 13,65\% dari total order sepatu Terrex AX2 Goretex, sedangkan jumlah defect yang ditargetkan perusahaan sebesar $3 \%$.

Untuk mengatasi permasalahan di atas, perlunya suatu metode yang tepat untuk mencari akar dari penyebab kecacatan untuk penurunan tingkat kecacatan produk pada perusahaan ini. Metode yang dapat di gunakan untuk mengatasi kecacatan produk yaitu dengan mengidentifikasi alur proses kerja pada lantai produksi perusahaan dengan metode Fault Tree Analysis (FTA), Selanjutnya membuat analisis untuk perbaikan dengan menggunakan metode Failure Mode and Effect Analysis (FMEA). FMEA merupakan teknik yang di gunakan untuk mendefinisi, mengidentifikasi, dan menghilangkan kegagalan dan masalah pada proses produksi, setelah itu melakukan pembobotan nilai dan pengurutan berdasarkan Risk Priority Number (RPN).

\section{METODE PENELITIAN}

Dalam memecahkan masalah pada penelitian yang diamati, dibutuhkan langkah-langkah untuk menguraikan pendekatan dan model dari masalah tersebut. Langkah-langkah yang dilakukan adalah:

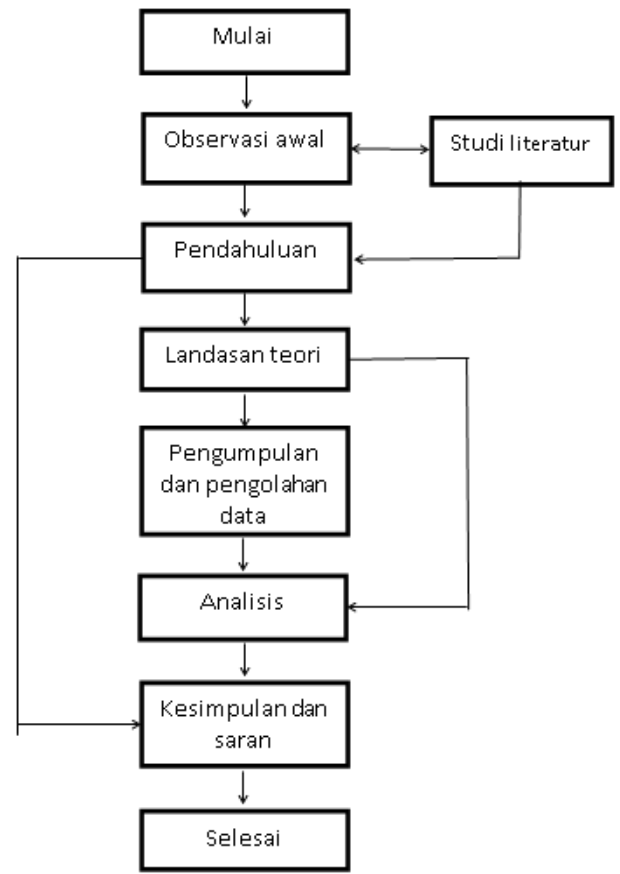

Gambar 2 Flowchart metodelogi penelitian 


\section{HASIL DAN PEMBAHASAN}

\section{Data Kegagalan Produksi}

Data yang dikumpulkan adalah data produksi Sepatu Terrex AX2 Goretex. Data berupa jumlah produksi per hari dan jumlah produk cacat selama bulan Januari, Febuari, Maret 2017. Data diperoleh melalui wawancara dan pengumpulan catatan dokumentasi perusahaan.

Berdasarkan pengamatan pada proses produksi plant5 cell 1, maka diperoleh jumlah kegagalan dibawah ini:

Tabel 1 Data Jumlah Kegagalan Bulan Januari

\begin{tabular}{|c|c|c|c|c|c|}
\hline No & Fungsi Proses & $\begin{array}{c}\text { Jumlah } \\
\text { Produksi }\end{array}$ & $\begin{array}{c}\text { Jumlah } \\
\text { Produk } \\
\text { Gagal }\end{array}$ & $\begin{array}{c}\text { Proporsi } \\
\text { Produk } \\
\text { Gagal }\end{array}$ & Persen \\
\hline 1 & Cutting & 7.200 & 225 & 0,031 & 3,13 \\
\hline 2 & Preparation & 7.200 & 242 & 0,034 & 3,56 \\
\hline 3 & Sewing & 7.200 & 306 & 0,043 & 4,25 \\
\hline 4 & Assembling & 7.200 & 257 & 0,037 & 3,57 \\
\cline { 5 - 7 } & \multicolumn{2}{r|}{} & Total & 0,143 & 14,31 \\
\cline { 5 - 7 }
\end{tabular}

Sumber: Data Produksi plant 5 cell 1, 2017

Tabel 2 Data Jumlah Kegagalan Bulan Februari

\begin{tabular}{|c|c|c|c|c|c|}
\hline No & Fungsi Proses & $\begin{array}{c}\text { Jumlah } \\
\text { Produksi }\end{array}$ & $\begin{array}{c}\text { Jumlah } \\
\text { Produk } \\
\text { Gagal }\end{array}$ & $\begin{array}{c}\text { Proporsi } \\
\text { Produk } \\
\text { Gagal }\end{array}$ & Persen \\
\hline 1 & Cutting & 10.400 & 317 & 0,030 & 3,05 \\
\hline 2 & Preparation & 10.400 & 342 & 0,033 & 3,29 \\
\hline 3 & Sewing & 10.400 & 364 & 0,035 & 3,50 \\
\hline 4 & Assembling & 10.400 & 353 & 0,034 & 3,39 \\
\hline
\end{tabular}

Sumber: Data Produksi plant 5 cell 1, 2017

Tabel 3 Data Jumlah Kegagalan Bulan Maret

\begin{tabular}{|c|c|c|c|c|c|}
\hline No & Fungsi Proses & $\begin{array}{c}\text { Jumlah } \\
\text { Produksi }\end{array}$ & $\begin{array}{c}\text { Jumlah } \\
\text { Produk } \\
\text { Gagal }\end{array}$ & $\begin{array}{c}\text { Proporsi } \\
\text { Produk } \\
\text { Gagal }\end{array}$ & Persen \\
\hline 1 & Cutting & 4.800 & 143 & 0,030 & 2,98 \\
\hline 2 & Preparation & 4.800 & 160 & 0,033 & 3,33 \\
\hline 3 & Sewing & 4.800 & 181 & 0,038 & 3,77 \\
\hline 4 & Assembling & 4.800 & 168 & 0,035 & 3,50 \\
\cline { 5 - 6 } & & Total & 0,136 & 13,58 \\
\hline
\end{tabular}

Sumber: Data Produksi plant 5 cell 1, 2017 
Tabel 4 Data Rata-Rata Bulan Januari, Febuari, Maret

\begin{tabular}{|c|c|c|c|}
\hline No & Bulan & Jumlah Produksi & $\begin{array}{c}\text { Jumlah } \\
\text { Defect }\end{array}$ \\
\hline 1 & Januari & 7.200 & 1.030 \\
\hline 2 & Febuari & 10.400 & 1.376 \\
\hline 3 & Maret & 4.800 & 652 \\
\hline & Total & 22.400 & 3.058 \\
\hline
\end{tabular}

Sumber: Data Produksi plant 5 cell 1, 2017

Rata-Rata $=$ Jumlah Defect $:$ Jumlah Produksi $=3.058: 22.400=13,65 \%$

Berdasarkan data diatas rata-rata kegagalan pada proses produksi bulan Januari, Febuari, Maret 2017 berjumlah 13,65\% dan melebihi dari toleransi yang di tentukan perusahaan yang sebesar 3\% dari hasil produksi per fungsi proses.

\section{Fault Tree Analysis (FTA)}

Berdasarkan jumlah kegagalan pada proses yang melebihi batas toleransi yang ditetapkan perusahan dan kegagalan tersebut terdapat pada proses inti pembuatan sepatu, langkah selanjutnya adalah membuat pohon kesalahan (Fault Tree) pada keempat fungsi proses. Bisa dilihat pada gambar dibawah ini:

\section{a. Fault Tree Analysis Cutting}

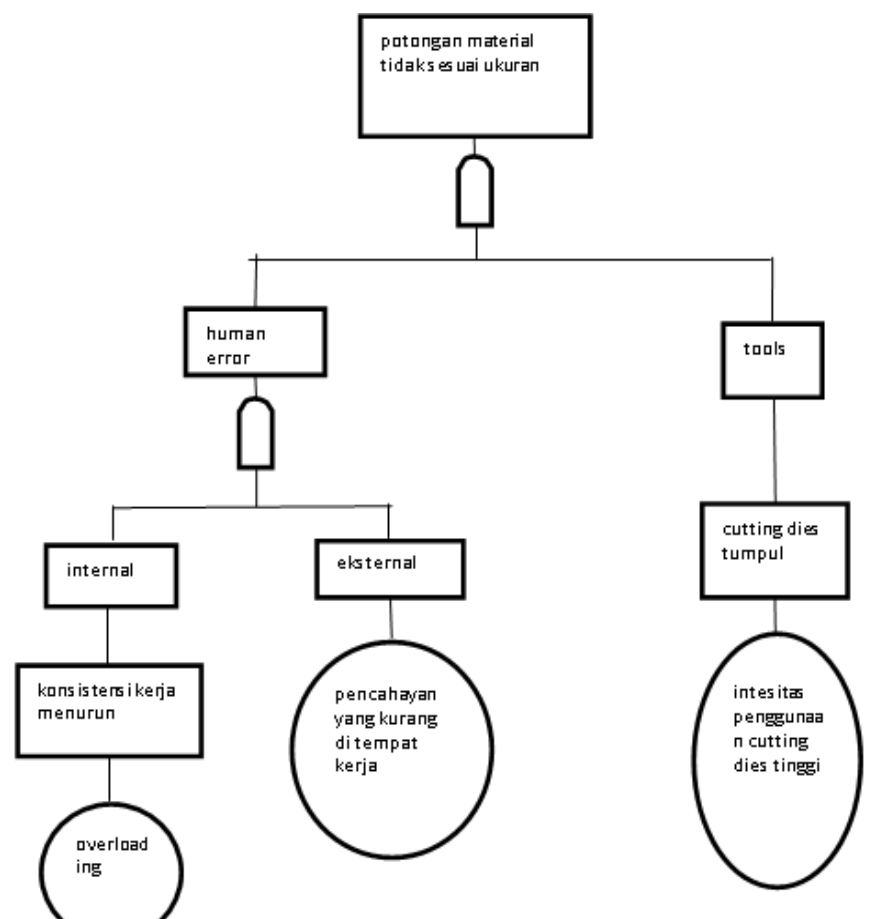

Gambar 3 FTA Cutting 
b. Fault Tree Analysis Preparation

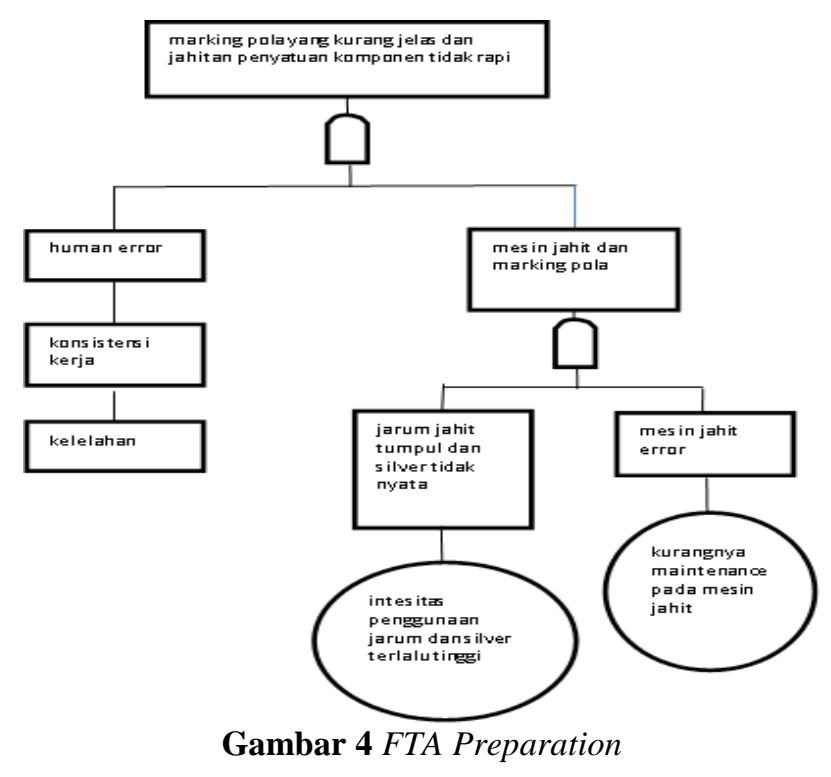

c. Fault Tree Analysis Sewing

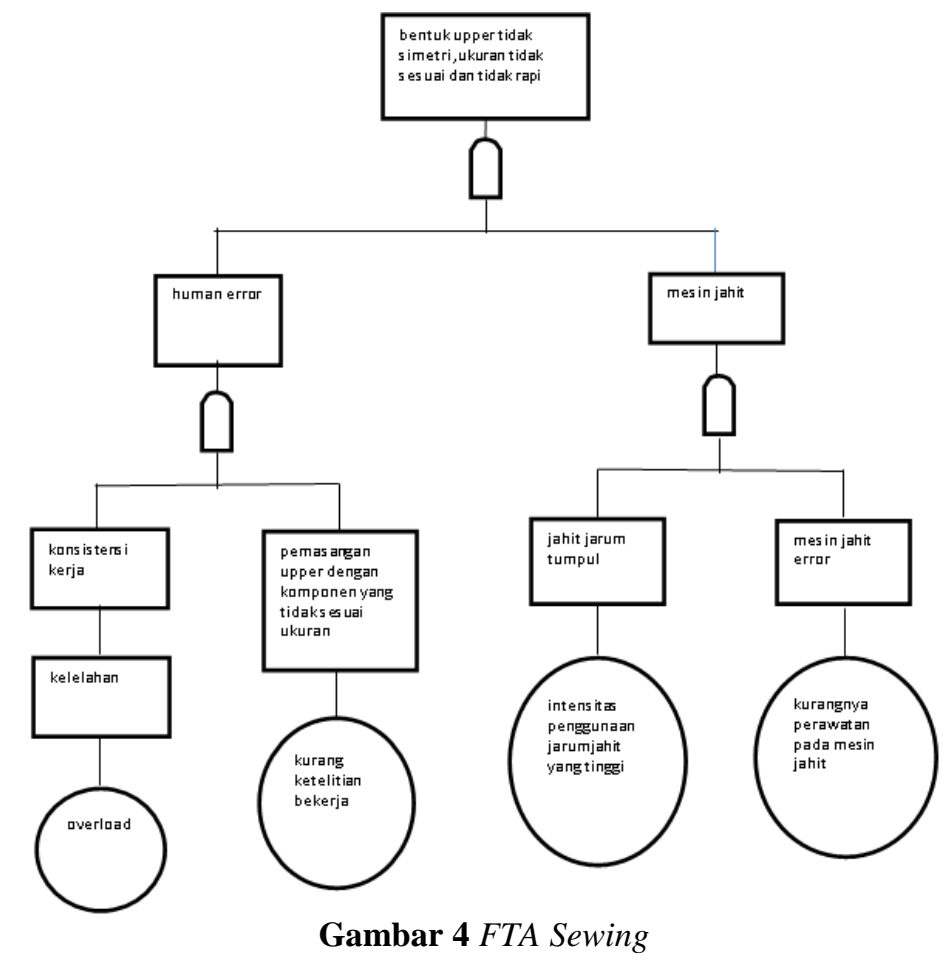


d. Fault Tree Analysis Assembling

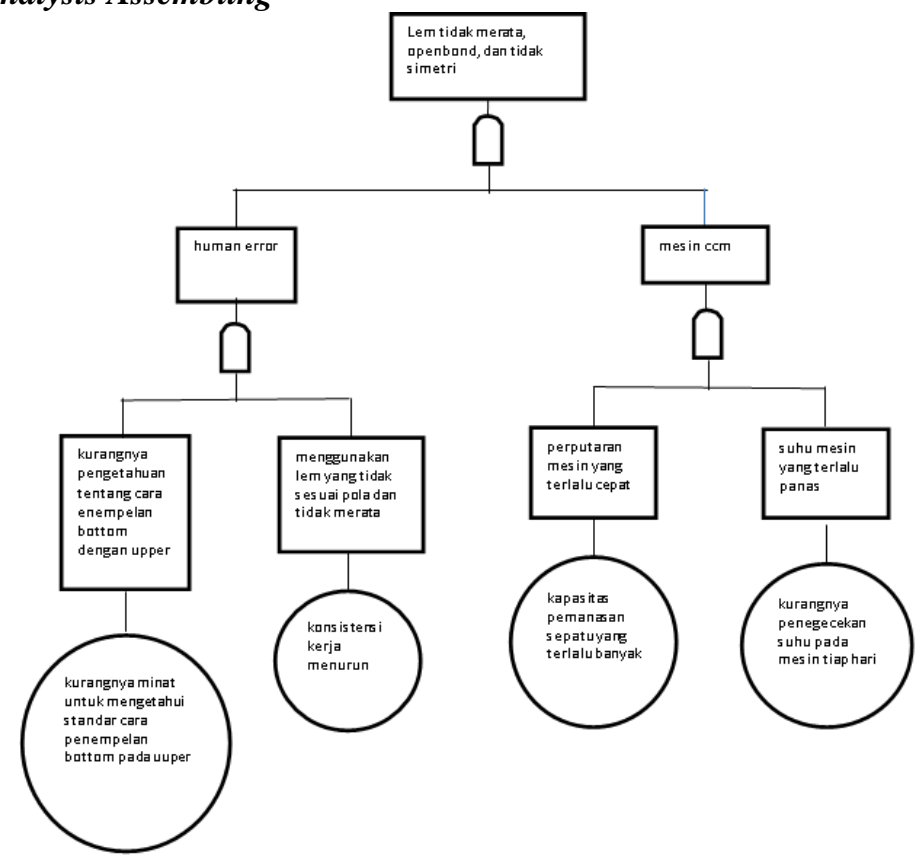

Gambar 5 FTA Assembling

\section{Failure Mode Effect Analysis (FMEA)}

Tabel 5 Proses Failure Mode Effect Analysis

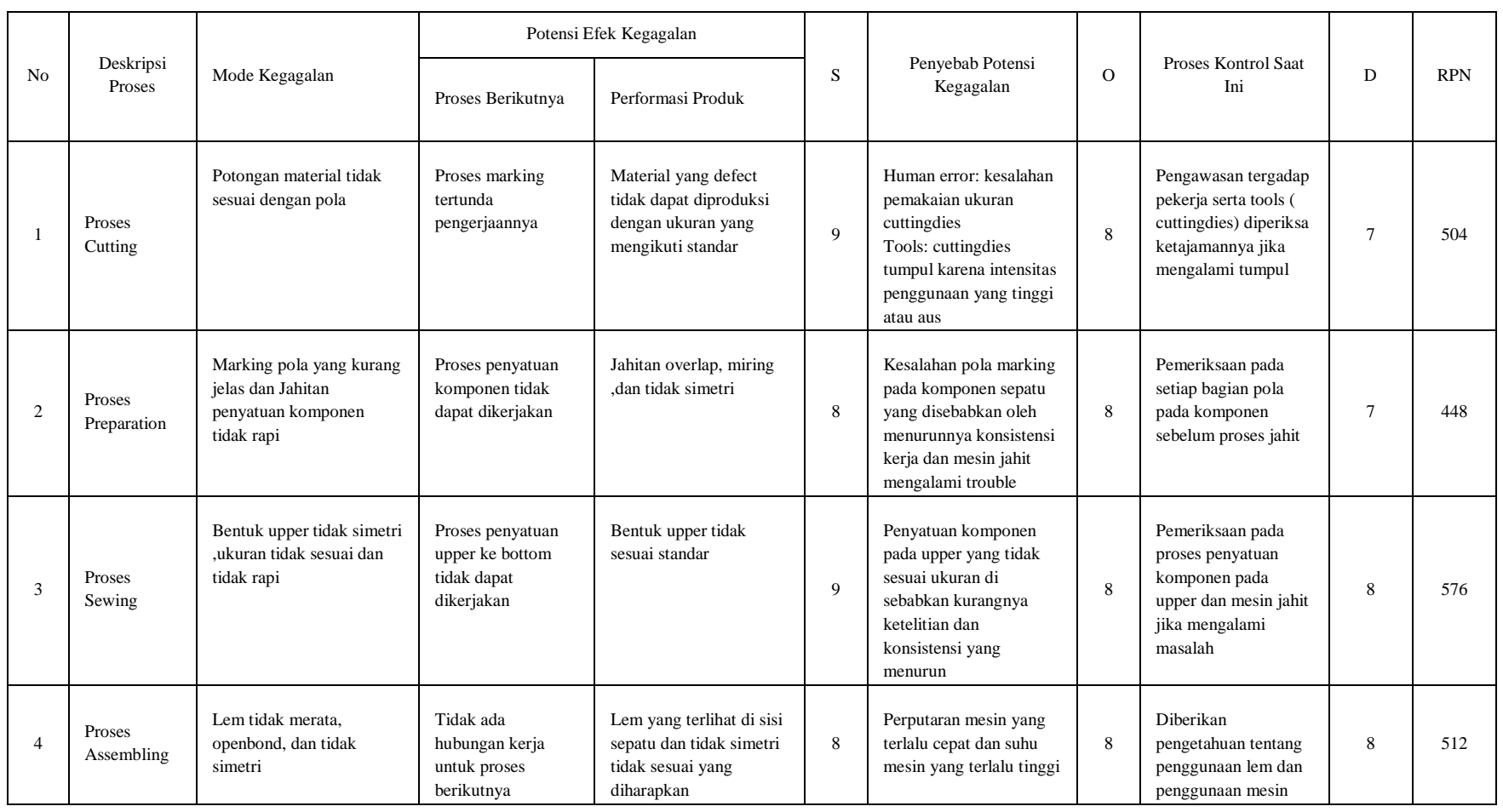


Tabel 6 Risk Priority Number (RPN)

\begin{tabular}{|c|c|c|c|c|c|c|}
\hline No & $\begin{array}{c}\text { Deskripsi } \\
\text { Proses }\end{array}$ & Mode Kegagalan & $\mathrm{S}$ & $\mathrm{O}$ & $\mathrm{D}$ & RPN \\
\hline 1 & Sewing & $\begin{array}{l}\text { Bentuk upper tidak } \\
\text { simetri, ukuran tidak } \\
\text { sesuai, dan jahitan tidak } \\
\text { rapi }\end{array}$ & 9 & 8 & 8 & 576 \\
\hline 2 & Assembling & $\begin{array}{l}\text { Lem tidak merata, } \\
\text { openbond, dan tidak } \\
\text { simetri }\end{array}$ & 8 & 8 & 8 & 512 \\
\hline 3 & Cutting & $\begin{array}{l}\text { Potongan material tidak } \\
\text { rapi dan tidak sesuai } \\
\text { ukuran }\end{array}$ & 9 & 8 & 7 & 504 \\
\hline 4 & Preparation & $\begin{array}{l}\text { Marking pola tidak sesuai } \\
\text { dan jahitan tidak rapi }\end{array}$ & 8 & 7 & 8 & 448 \\
\hline
\end{tabular}

Berdasarkan pengurutan nilai RPN dan berdasarkan diagram pareto diatas, diambil 2 proses yang memiliki nilai RPN tertinggi yaitu proses sewing, dan assembling. Dua proses tersebut memiliki peranan penting dalam pembuatan sepatu. Dampak yang ditimbulkan dari kedua proses kegiatan produksi ini, sangat berpengaruh besar terhadap penurunan kualitas produk sepatu yang berada diluar batas toleransi. Hal ini menandakan bahwa pada proses pembuatan sepatu terdapat mode kegagalan yang harus dilakukan perbaikan. Perbaikan yang akan dilakukan untuk kedua proses tersebut yaitu perbaikan berdasarkan penyebab-penyebab kegagalan yang telah dianalisis berdasarkan Fault Tree Analysis (FTA) dan Failure Mode and Effect Analysis (FMEA) sehingga diketahui permasalahan yang terjadi untuk dilakukannya perbaikan.

\section{Usulan Perbaikan}

Tabel 7 Usulan Perbaikan

\begin{tabular}{|c|c|c|c|}
\hline No & $\begin{array}{l}\text { Deskripsi } \\
\text { Proses }\end{array}$ & Penyebab Kegagalan & Usulan Perbaikan \\
\hline \multirow[b]{2}{*}{1} & \multirow[b]{2}{*}{ Sewing } & $\begin{array}{c}\text { Kesalahan pemakaian } \\
\text { ukuran komponen terhadap } \\
\text { upper }\end{array}$ & $\begin{array}{c}\text { Melakukan pengawasan dan } \\
\text { pengecekan pada proses } \\
\text { sewing }\end{array}$ \\
\hline & & Mesin jahit error & $\begin{array}{c}\text { Melakukan perawatan dan } \\
\text { pemeriksaan pada mesin jahit } \\
\text { secara berkala bukan pada } \\
\text { saat mesin mengalami } \\
\text { trouble }\end{array}$ \\
\hline \multirow{3}{*}{2} & \multirow{3}{*}{ Assembling } & $\begin{array}{l}\text { Penempelan yang tidak } \\
\text { sesuai pola marking }\end{array}$ & $\begin{array}{c}\text { Melakukan pengawasan dan } \\
\text { pengecekan pada proses } \\
\text { pengeleman setiap satu jam } \\
\text { sekali }\end{array}$ \\
\hline & & $\begin{array}{l}\text { Suhu mesin yang terlalu } \\
\text { panas }\end{array}$ & $\begin{array}{l}\text { Dilakukan pengecekan suhu } \\
\text { mesin setiap satu jam sekali }\end{array}$ \\
\hline & & Mesin ccm error & $\begin{array}{c}\text { Melakukan peraatan dan } \\
\text { pemerikasaan secara berkala } \\
\text { bukan hanya pada saat mesin } \\
\text { rusak }\end{array}$ \\
\hline
\end{tabular}




\section{KESIMPULAN}

Dari penelitian yang dilakukan, dapat ditarik kesimpulan yaitu sebagai berikut:

- Jumlah defect pada bulan Januari, Febuari, dan Maret 2017 sebesar 13,65\% melebihi batas toleransi yang di tetapkan oleh perusahaan sebesar $3 \%$.

- Jenis cacat dan penyebab kegagalan berdasarkan diagram pareto Risk Priority Number (RPN) terdapat 2 proses yang memiliki nilai tertinggi yaitu proses sewing dan proses assembling.

- $\quad$ PT. Panarub Industri masih memiliki kekurangan dalam proses pengendalian kualitas.

- Usulan perbaikan pada cacat proses sewing dan assembling melakukan pengawasan dan pemeriksaan terhadap proses yang critical dan pemeriksaan mesin secara berkala dan penambahan QC di setiap akhir proses atau bagian output.

\section{DAFTAR PUSTAKA}

Ariani, D.W. (2012) "Manajemen Kualitas, Jakarta: Ghalia Indonesia, [online] (http://www.digilib.uin_suka.ac.id, diakses tanggal 13 agustus 2017)

Ahmad, Y., \& Aulawi, H. (2016). Analisa Pengendalian Kualitas Produk Peci Jenis Overset yang Cacat di PD. Panduan Ilahi dengan Menggunakan Fault Tree Analysis (FTA) dan Failure Mode and Effect Analysis (FMEA). Jurnal-setgarut.ac.id. vol. 14 no. 1.

Arianto, M., \& Mahmudah, N. (2014). Analisis Kepuasan Konsumen di Jatiroso Catering Service. Jurnal Bisnis, Manajemen \& Perbankan vol 1 No. 2. Fakultas Ekonomi Universitas Muhammadiyah Sidoarjo.

Diana., Hari, A., Yoanita, Y. (2015). Usulan Pengendalian Kualitas Produk Isolator Dengan Metode Failure Mode and Effect Analysis dan Fault Tree Analysis. Jurnal Teknik Industri ITENAS no. 2 vol 03.

Effendi, M.S., \& Arifin, M.K. (2015). Tesis: Perbedaan Risk Priority Number dalam Failure Mode and Effect Analysis (FMEA) Sistem Alat Berat Heavy Duty Truck HD. Spektrum Industri, 2015vol.13, no 1-114.

Pranata, D. (2011). Skripsi: Penggunaan Metode Failure Mode and Analysis (FMEA) untuk Mengurangi Cacat Produk Kain Denim di PT. Garuda Mas Semesta. Universitas Widyatma, Bandung .

Qurrachman, T. (2016). Fault Tree Analysis $\quad$ T. www.Taufiqurrachman.weblog.esaunggul.ac.id, diakses tanggal 13 Agustus 2017).

Octavia (2010). Skripsi: Aplikasi Metode FMEA untuk Pengendalian Kualitas Pada Proses Heat Treatment PT. Mitsuba Indonesia. Program Studi Teknik Industri Universitas Mercu Buana.

Sulistyoko, E. (2008). Skripsi: Analisa Penerapan Program Keselamatan Kerja Dalam Usaha Meningkatkan Produktivitas Kerja dengan Pendekatan Failure Tree Analyis (FTA). Universitas Muhammadiyah Surakarta. 